\title{
Factors in Developing Creative Industry
}

\author{
Maskarto Lucky Nara Rosmadi \\ Management Department, Institute of Economic Science (STIE) Kridatama Bandung, Indonesia \\ maskartolucky@gmail.com
}

\begin{abstract}
This study aims to find out and analyze factors to support the development of creative industries. The research method used is a qualitative method with a descriptive approach. From the results of research conducted to get creative results because it is supported by highly reliable and high-quality human resources. The constraints used in developing the creative industry are snacks that are used to increase production and also from the banking sector.
\end{abstract}

Keywords: creative industry; human resources; product quality

\section{Introduction}

Creative economic development is the foundation for economic growth in Indonesia [1]. This shows that creative industries have good prospects to be developed and have competitiveness and competitive advantage if managed well [2] - [6]. Creative industries also contribute significantly to the economies of local communities and local governments and contribute to job creation [7], [8], [9].

In managing the business of the creative industries of business people in addition to developing their business, they must also be able to create added value from the products they produce and be consistent in providing services and can maintain product quality [10] - [13]. Because the quality of human resources must have the ability to make extensive networks both manually and utilize information technology especially for product marketing and business development [14] - [17].

However, the role of the government in the development of the creative industry is still low due to several factors, including relating to regulations and policies. This is due to the existence of regional autonomy and the concept of Local Economic Development, so that the growth and development of local businesses is a collaboration between business actors, local governments, and private companies [18]. From the description above, researchers can deal with problems related to what factors can support the development of the creative industry. The purpose of this study is to find out and analyze the supporting factors in developing the creative industry.

\subsection{Creative Industry}

\section{Review of Literature}

Business activities can grow and develop for a long period of time is the goal of each company. Competitiveness, innovation, creativity, and the quality of the products produced must be in accordance with the needs of consumers and can adapt to a dynamic environment. With the development of science and information technology that is so fast, the creative industry must be able to create competitive advantages to be accepted by consumers.

With the existence of small industries (creative industries), the country's economic growth (GDP/Domestic Brutto Product) will increase, poverty levels will decrease, and can absorb a considerable workforce [19], [20]. Creative industry sectors include advertising, broadcasting, architecture, art, crafts, design, fashion, gastronomy, music, publishing, theater and technology. This sector is a major force in entrepreneurship and innovation and supports increasing social development and providing employment [21]. 
The results of research conducted by Bhardwaj \& Punia [22], Khoshouei, Oreyzi, \& Noori [23], Savaneviciene, Ciutiene, \& Rutelione [24], Ali \& Mortazvi [25] can be concluded that creative industries can grow and develop not only because have quality products, but also must be supported by management and qualified human resources.

\subsection{Human Resources}

In building business activities, human resources are the main source that is not replaced by other resources. In creative industry efforts, resources are needed primarily to elevate local wisdom-based people's economy. The quality and competence of human resources is needed especially for the development of creative industries because this sector has a very potential role in economic growth [26]. To produce quality, creative and innovative human resources, support from various parties is needed, including the world of education [27] - [29].

The results of the study were carried out by Leede, Looise, \& Alders [30], McDonoughill [31], Merlo, Hartel, Mann, \& Hirst [32], Shin \& Zhou [33], Yuan \& Zhou [34]. humans in developing creative industries are needed because they have ideas, innovation, and creativity, especially in product development. Improving the quality of human resources can be done through training and sharing the knowledge and experience of fellow employees.

\subsection{Product quality}

The success and progress of a business organization is not only supported by quality human resources but also supported by the quality of production. Innovation, creativity, and the usefulness of the products it produces, become the main capital for the development of creative industries business [35]. In creative industries which are populist economies, product quality is the main key to gain consumer interest and become competitiveness for similar companies [36], [37], [38]. The results of research conducted by Kaynak [39], Kaynak [40] , Duggirala, Rajendran, Anantharaman [41], Douglas \& Judge Jr. [42] It can be concluded, that the quality of products can win the competition and attract the attention of consumers. In addition, product quality can also increase customer satisfaction and increase the number of sales.

\section{Research Methods}

The research was carried out The research was conducted from February to May 2018. The method used was a qualitative method with a descriptive explorative approach. The object of research is the snack business with the trademark @ Kidas which is located on Jalan Terusan Kopo Margahayu Kp. Cicukang RT. 03 RW. 020 Mekarrahayu Village, Margaasih District, Bandung Regency. The type of data collected is primary data obtained through in-depth interviews with information sources (informants).

In conducting surveys, researchers use a personal approach (unstructured questionnaire) to obtain information related to the bag industry business. Data analysis techniques in this study used a descriptive qualitative interactive model in the form of data collection, data reduction, display data, and conclusions / interpretative verification. 


\section{Results and Discussion}

The research conducted in the creative industry of the snack subsector is the one that produces the basic ingredients of cassava chips, macaroni, and fried meatballs. This business was established in December 2017. Some of the products it produces can be seen in the following picture:
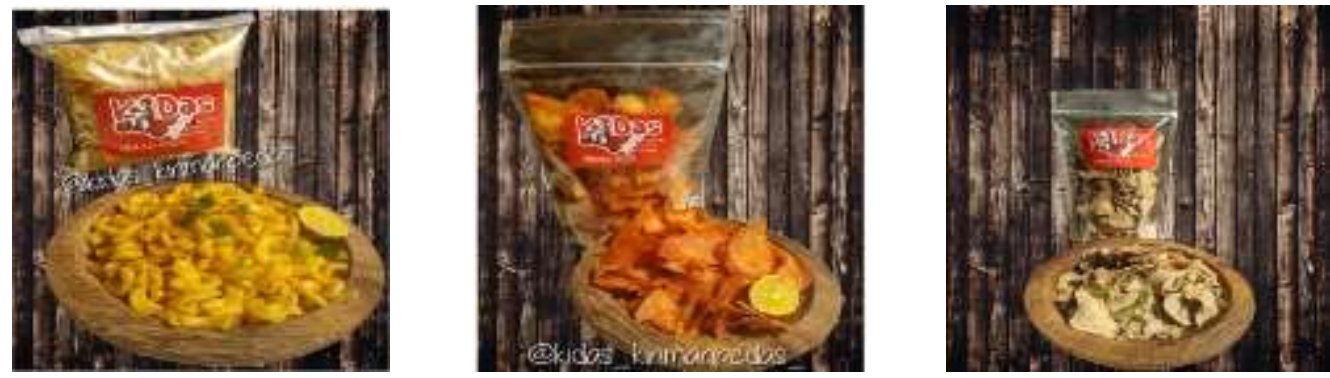

Figure 1. Types of MSMEs @ Kidas

From Figure 1, it can be explained that of the three basic ingredients, several variants are made, including spicy macaroni, savory macaroni, spicy cassava chips, savory cassava chips, spicy fried meatballs, and savory fried meatballs. The @ Kidas business in its business activities cooperates with other industry players and they only package and market it. The production capability of @ Kidas since its establishment can be seen in the following table:

Table 1. Total Production @ Kidas Period December 2017 - March 2018

\begin{tabular}{|c|l|c|c|c|c|}
\hline \multirow{2}{*}{ No } & \multicolumn{2}{|c|}{ Product } & \multicolumn{4}{|c|}{ Capacity/month (kg) } \\
\cline { 3 - 6 } & & Dec & Jan & Feb & Mar \\
\hline 1 & Macaroni (various flavors) & 10 & 15 & 15 & 20 \\
\hline 2 & Cassava chips (various flavors) & 20 & 20 & 30 & 30 \\
\hline 3 & Fried meatballs (various flavors) & 7 & 10 & 12 & 12 \\
\hline
\end{tabular}

Source: @Kidas Management

From table 1 above it can be explained, that the production of @Kidas is very promising to be developed. According to Riyana and Novya, the owner and manager of @ Kidas, the business he pioneered was the development of a small business carried out while still in college. After completing college they finally founded @ Kidas and marketed it online. Furthermore they explained that the difficulty of finding work is a supporting factor for entrepreneurship. Currently they have employed two employees for the packaging section while administration and marketing are still held by them. This explanation supports Mu's opinion [14], Anton et al. [19] and Gunasekaran et al. [20], that the support of quality products and quality resources can accelerate the development of creative industry businesses and have an impact on increasing people's incomes and absorbing a large number of workers .

The online marketing they are doing is only limited through Facebook, WA, and Instagram. However, consumers have spread across several islands in Indonesia, including consumers from Malaysia and Singapore. This can be seen in the following graph: 

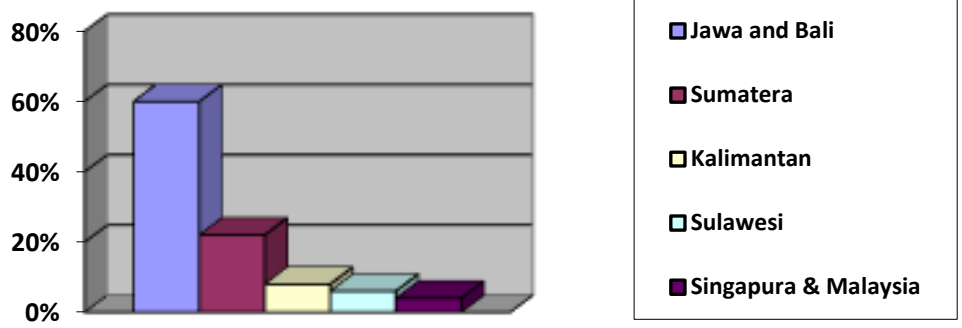

Source: data processed

Graph 1. Percentage of Consumer Distribution @ Kidas

From graph 1 above, it can be explained that the distribution of @Kidas products, namely Java and Bali 60\%, Sumatra 22\%, Kalimantan 8\%, Sulawesi 6\%, Singapore and Malaysia 4\%. The limited capital and knowledge of information technology to market production is an obstacle currently faced.

\section{Conclusion}

From the description above, it can be seen that the factors for developing the creative industry, especially in the snack subsector, are focused on product quality, quality of human resources, and other supporting factors. To optimize product quality, several supporting facilities are needed, including modern equipment, quality raw materials, and capital. Support from the regional government is expected to improve the quality of human resources by providing counseling and training related to product marketing and the role of banks to improve the ability of business people to develop their activities.

\section{References}

[1] Jianpeng Zhang and Jitka Kloudova, "Factors Which Influence the Growth of Creative Industries: Cross-section Analysis in China," International Scientific Journal, vol. 1, no. 1, pp. 519, Oktober 2011.

[2] Radix Iwan M. Sipayung, Sucherly, Faisal Affif, and Imas Soemaryani, "The Influence of Market Attracttiveness and Dynamic Capability on Competitive Strategy and the Implementations on Business Performance of Creative Industry in West Java," South East Asia Journal of Contemporary Business, Economics and Law, vol. 11, no. 2, pp. 95-105, December 2016.

[3] Thomas L. Wheelen, J. David Hunger, Alan N. Hoffman, and Charles E. Bamford, Strategic Management And Business Policy: Globalization, Innovation, and Sustaibility, 14th ed.: Pearson, 2015.

[4] J.A. Pearce and R.B. Robinson, Strategic Management - Planning for Domestic and Global Competition, International Student Edition ed.: Mc Graw-Hill International, 2015.

[5] Roger J. Best, ). Market-Based Management, Strategies for Growing Customer Value and Profitability, 6th ed. New Jersey: Prentice Hall: Upper Saddle River, 2013.

[6] Shu-Mei Tseng and Pei-Shan Lee, "The Effect of Knowledge Management Capability and Dynamic Capability on Organizational Performance," Journal of Enterprise Information Management, vol. 27, no. 2, pp. 158-179, 2014.

[7] Jason Potts, "Why the Creative Industries Matter to Economic Evolution," Economics of Innovation and New Technology, vol. 18, no. 7, pp. 663-673, Oktober 2009. 
[8] Desmond Hui, The Creative Industries and Entrepreneurship in East and Souteast Asia. Enterpreuneship in the Creative Industries. An International Perspective. Cheltenham: Edward Elgar Publishing Limited, 2007.

[9] Mohammad Yusri, Sirojuzilam, Badaruddin, and Irsyad, "Program Priorities Local Economic Development through Creative Industries Household Based in Realizing Sustainable Development of The Region," Journal of Economics and Sustainable Development, vol. 7, no. 4, pp. 60-67, 2016.

[10] Eugenija Martinaityte and Rusne Kregzdaite, "The Factors of Creative Industries Development in Nowadays Stage," Journal of Economics and Sociology, vol. 8, no. 1, pp. 55-70, May 2015.

[11] Fan-qi Zeng, Xiang-Zhi Bu, and Li Su, "Study on Entrepreneurial Process Model for SIFE Student Team Based on Timmons Model," Journal of Chinese Entrepreneurship, vol. 3, no. 3, pp. 204-214, 2011.

[12] Yuli Zhang and Jun Yang, "New Venture Creation: Evidence from an Investigation into Chinese Entrepreneurship," Journal of Small Business and Enterprise Development, vol. 13, no. 2, pp. 161-173, 2006.

[13] Dedi Hadian, Senen Machmud, Dudung Juhana, and Iwan Sidharta, "Measuring Theory Planned Behavior of Students to Become Entrepreneurs (Case Study at School of Economic Pasundan Bandung, Indonesia)," International Journal of Human Resource Studies, vol. 5, no. 3, pp. 131147, 2015.

[14] Jifeng $\mathrm{Mu}$, "Networking Capability, New Venture Performance and Entrepreneurial Rent," Journal of Research in Marketing and Entrepreneurship, vol. 15, no. 2, pp. 101-123, 2013.

[15] Senen Machmud and Iwan Sidharta, "Entrepreneurial Motivation and Business Performance of SMEs in the SUCI Clothing Center, Bandung, Indonesia," DLSU Business \& Economics Review, vol. 25, no. 2, pp. 63-78, January 2016.

[16] Odd Jarl Borch, Anniken Forde, Lars Ronning, Ingebjorg Kluken Vestrum, and Gry Agnete Alsos, "Resource Configuration and Creative Practices of Community Entrepreneurs," Journal of Enterprising Communities: People and Places in the Global Economy, vol. 2, no. 2, pp. 100-123, 2008.

[17] Syed Awais Ahmad Tipu and Faisal manzoor Arain, "Managing Success Factors in Entrepreneurial Ventures: a Behavioral Approach," International Journal of Entrepreneurial Behavior \& Research, vol. 17, no. 5, pp. 534-560, 2011.

[18] Laurie Kaye Nijaki and Gabriela Worrel, "Procurement for sustainable local economic development," The International Journal of Public Sector Management, vol. 25, no. 2, pp. 133153, 2012.

[19] Setyawan Agus Anton, Isa Muzakin, Wadji Farid Muhammad, Syamsudin, and Nugroho Permono Sidiq, "An Assessment of SME Competitiveness in Indonesia," Journal of Competitiveness, vol. 7, no. 2, pp. 60-74, 2015.

[20] Angappa Rai Gunasekaran, K. Bharatendra, and Michael Griffin, "Resilience and Competitiveness of Small and Medium Size Enterprises: An Empirical Research," International Journal of Production Research, vol. 49, no. 18, pp. 5489-5509, 2011.

[21] Joe Tidd and John R. Bessant, Managing Innovation: Integrating Technological, Market and Organizational Change, 5th ed.: Chichester-Wiley, 2013.

[22] Anand Bhardwaj and B.K. Punia, "Managerial competencies and their influence on managerial performance: A literature review," International Journal of Advances Research in Management and Social Sciences, vol. 2, no. 5, pp. 70-84, May 2013.

[23] Mahdieh Sadat Khoshouei, Hamid Reza Oreyzi, and Aboulghasem Noori, "The Eight Managerial Competencies : Essential Competencies for Twenty First Century Managers," Iranian Journal of 
Management Studies, vol. 6, no. 2, pp. 131-152, 2013.

[24] Asta Savaneviciene, Ruta Ciutiene, and Ausra Rutelione, "Examining Leadership Competencies during Economic Turmoil," Procedia-Social and Behavioral Sciences, vol. 156, pp. 41-46, November 2014.

[25] Shirazi Ali and Saeed Mortazvi, "Effective management performance a competency based perspective," International Review of Business Research Papers, vol. 5, no. 1, pp. 1-10, January 2009.

[26] Roberta Comunian and Alessandra Faggian, "Higher education, human capital, and the creative economy," Environment and Planning C: Government and Policy, vol. 32, no. 3, pp. 381-383, 2014.

[27] J. Taylor, "Unweaving the Rainbow: Research, Innovation and Risk in a Creative Economy," AHCR, London, Discussion Paper 2005.

[28] Stuart D. Cunningham, The humanities, creative arts and the innovation agenda, In Wissler et al., Eds. Flaxton, Qld, Australia: Media and Design:, 2004.

[29] Geoffrey Crossick, Knowledge transfer without widgets: The challenge of the creative economy, In Lecture ed. London, Inggris: Royal Society of Arts, 2006.

[30] Jan de Leede, Jan C. Looise, and Ben C.M. Alders, "Innovation, improvement and operations: an exploration of the management of alignment," International Journal of Technology Management, vol. 23, no. 4, pp. 353-368, 2002.

[31] Edward F. McDonoughill, "Investigation of factors contributing to the success of crossfunctional teams," Journal of Product Innovation Management, vol. 17, no. 3, pp. 221-235, May 2000.

[32] Andrew Pirola Merlo, Charmine Hartel, Leon Mann, and Giles Hirst, "How leaders influence the impact of affective events on team climate and performance in R\&D teams," Journal Leadership Quarterly, vol. 13, no. 5, pp. 561-581, October 2002.

[33] Shung Jae Shin and Jing Zhou, "Transformational leadership, conservation, and creativity: Evidence from Korea," The Academy of Management Journal, vol. 46, no. 6, pp. 703-714, December 2003.

[34] Feirong Yuan and Jing Zhou, "Differential effects of expected external evaluation on different parts of the creative idea production process and on final product creativity," Creativity Research Journal, vol. 20, no. 4, pp. 391-403, November 2008.

[35] VI Borisova, "Essential Characteristics And Market Of The Creative Industries' Product," Journal of Economic Alternatives, no. 1, pp. 113-122, March 2018.

[36] Rodney E. Smith and William F. Wright, "Determinants of Customer Loyalty and Financial Performance," Journal of Management Accounting Research, vol. 16, no. 1, pp. 183-205, December 2004.

[37] Alain Nadai, "Consumer 'Sovereignty' and Policy Issues in the Development of Product Ecolabels," Environment Policy and Governance, vol. 11, no. 1, pp. 14-26, January 2001.

[38] Marcus Wagner, "Sustainability and Competitive Advantage: Empirical Evidence on the Influence of Strategic," Ebvironmental Quality Management, vol. 14, no. 3, pp. 31-48, March 2005.

[39] Kevin B. Hendricks and Vinod R. Singhal, "Firm Characteristics, Total Quality Management, and Firm Performance," Journal of Operations Management, vol. 19, no. 3, pp. 269-285, May 2001.

[40] Hale Kaynak, "The Relationship Between Total Quality Management Practices and their Effects on Firm Performance," Journal of Operation Management, vol. 21, no. 4, pp. 405-435, July 2003.

[41] Mayuri Duggirala, Chandrasekharan Rajendran, and R.N. Anantharaman, "Provider-perceived dimensions of total quality management in healthcare," Benchmarking: An International Journal, vol. 15, no. 6, pp. 693-722, 2008. 